\title{
Assessment of Index Properties and Bearing Capacities of Soils for Infrastructure Foundations in Malete, Northcentral Nigeria
}

\author{
*0.0. Owoyemi and M. O. Awojobi \\ Department of Geology and Mineral Sciences Kwara State University, Malete, PMB 1530, llorin, Kwara State Nigeria \\ [Corresponding author: e-mail: lade. owoyemi@gmail.com; D :+2347036761892 ]
}

\begin{abstract}
Malete is a fast growing suburb with new buildings springing up daily. There has been no documented research on the physical properties and foundation bearing capacity of the soil in this area. This research aimed at determining the suitability of this soil as infrastructure foundation. Bulk samples taken from two selected locations at varrying depths of trial pits were tested for their index and shear strength properties using standard methods. Cone penetration resistance, California bearing ratio, compaction, consolidation and permeability characteristics were also assessed. The geotechnical properties determined varied significantly with depth except for specific gravity which did not vary significantly at $\mathrm{a}_{0.05}$ with depth. Soil samples from all pits consist mostly of poorly graded gravely sands with little fines. They contain medium to coarse grained sand fraction averagely above $85 \%$. Penetration resistance obtained from cone pentration test ranged from $700 \mathrm{kN} / \mathrm{m}^{2}$ to $950 \mathrm{kN} / \mathrm{m}^{2}$. The average safe bearing capacity estimated for strip footing using a factor of safety of 3 at depth of $1 \mathrm{~m}$ was not less than $473 \mathrm{kN} / \mathrm{m}^{2}$ anywhere in the study area. Samples from the two locations generally have good compaction parameters, medium to high permeability and low compressibilty. The highest bearing capacities were associated with the lateritized basement top. This implies that the safest depth to place infrastracture foundations in the area is the depth where lateritized basement rock is encountered.
\end{abstract}

\section{INTRODUCTION}

Recently, cases of collasped buildings in Nigeria has been on the rise. This calls for detailed geotechnical investigations of foundation soils so as to guard against reoccurrence of such ugly incidents. Material study of foundation soils to a large extent, serves as preventive measure for foundation failures. Nwankwoala and Warmate (2014), studied the foundation geotechnical properties of a site in Port Harcourt, Aduoye and Agbede (2014) used Terzaghi's equations to determine the bearing capacity of soil samples from Obafemi Awolowo University Campus. He found correlations between angle of internal friction and bearing capacity of the studied soils. Other researchers such as Ola (1988), Ogunsanwo (2002), Ige and Ogunsanwo (2009), Oyedele etal.(2011), Avwenagha et al. (2014) have worked on the geotechnical properties of foundation soils in Nigeria. However, there is presently no research on the physical properties and foundation bearing capacity of the soil in the study area. Malete is thereabout the fastest growing village in the vicinity of llorin. This is due to the establishment of Kwara State University campus in this rural area. While many new structures are springing up daily in the area, most of the building owners do not pay attention to the geotechnical properties of foumdation soils on which they are building. Hence, some of this building are showing signs of distress while some have suffered partial collapse. This study therefore investigates some geotechnical properties of the foundation soil in Malete using samples taken at varying depths and chainages from two selected locations.

\section{Location of the area}

The study area is located within Kwara State University Campus. Two loactions with rapid infrastructural developments were delinated. The two locations are underlain by migmatiticgneiss of the Migmatite-gneiss complex of Southwestern Nigeria (Geological Survey of Nigeria 1973). The area is on a watershed shedding its storm water into Apodu river as shown by Figure 1. The vegetation of Malete area is that of woody savannah. The trees include locust bean, "dogonyaro", "iya", sheer butter, and some thorny shrubs. Table 1 shows the location coordinates of trial pits at the samplinng locations. 


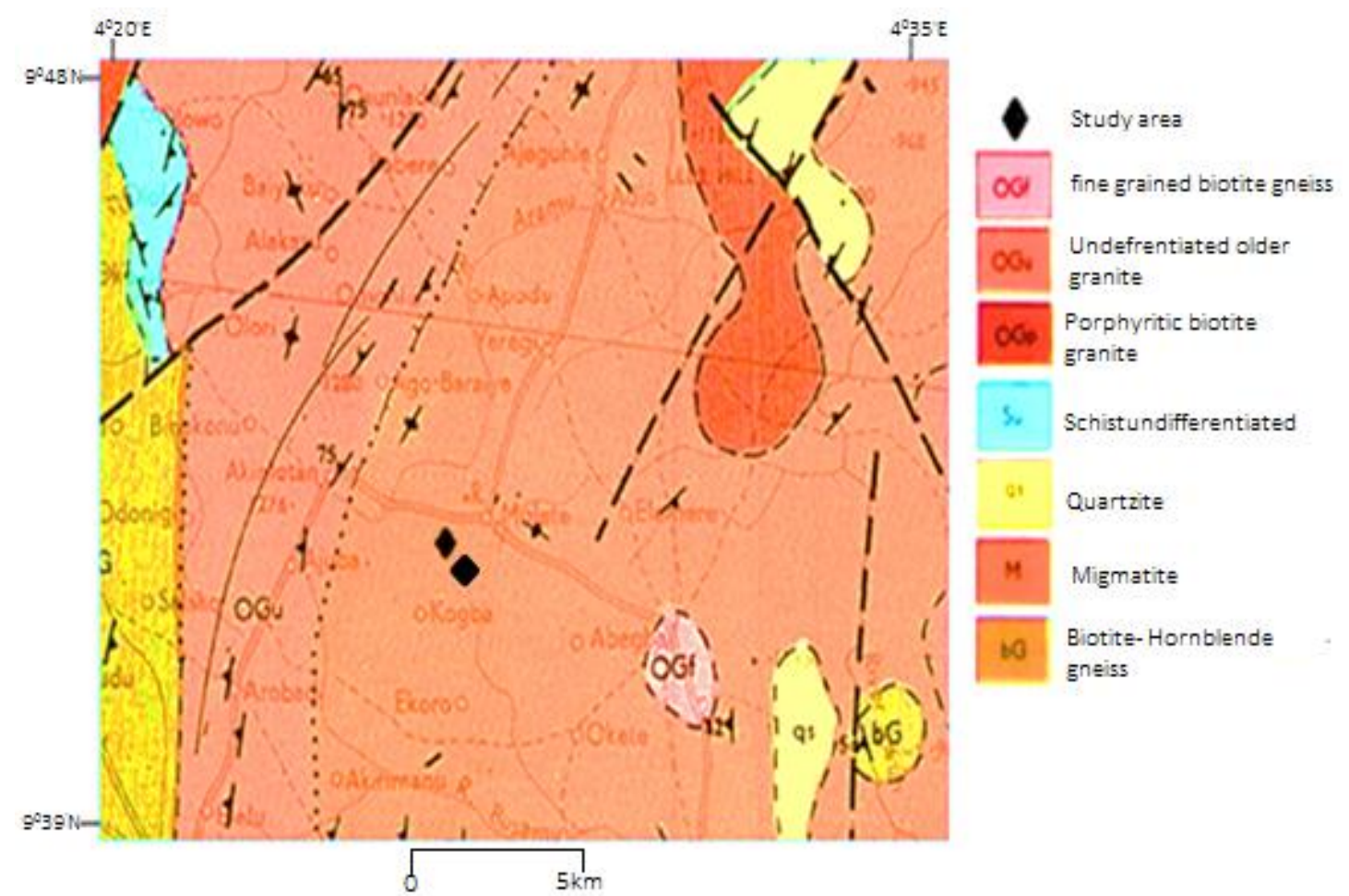

Figure 1: Geological map of Malete area (Modified from Geological Survey of Nigeria 1973).

Table 1: GPS Coordinates of trial pits.

\begin{tabular}{|c|c|c|c|c|c|c|c|}
\hline $\begin{array}{l}\text { Pit no. } \\
\text { (location 1) }\end{array}$ & latitude & longitude & $\begin{array}{l}\text { Altitude } \\
\text { (m) }\end{array}$ & $\begin{array}{l}\text { Pit no. } \\
\text { (location 2) }\end{array}$ & latitude & Longitude & $\begin{array}{l}\text { Altitude } \\
\text { (m) }\end{array}$ \\
\hline Pit1 -1 & $08043^{\prime} 29.1^{\prime \prime}$ & 0040 29'002.5" & 331 & Pit 2 -1 & $\begin{array}{l}080 \\
43.421\end{array}$ & 0040 29.532' & 330 \\
\hline Pit 1-2 & $08043^{\prime} 29.0^{\prime \prime}$ & 0040 29'002.9" & 332 & Pit 2-2 & $\begin{array}{l}080 \\
43.413^{\prime}\end{array}$ & $004029.541^{\prime}$ & 317 \\
\hline Pit1-3 & $08043^{\prime} 28.8^{\prime \prime}$ & 0040 29'003.1" & 335 & Pit 2-3 & $\begin{array}{l}080 \\
43.418^{\prime}\end{array}$ & $004029.5411^{\prime}$ & 332 \\
\hline Pit 1- 4 & $08043^{\prime} 28.7^{\prime \prime}$ & 0040 29'003.4" & 333 & Pit 2- 4 & $\begin{array}{l}080 \\
43.414^{\prime}\end{array}$ & $004029.552^{\prime}$ & 315 \\
\hline Pit 1 - 5 & $08043^{\prime} 28.6^{\prime \prime}$ & 0040 29'003.7" & 333 & Pit 2 - 5 & $\begin{array}{l}080 \\
43.411^{\prime}\end{array}$ & 004029.564 ' & 305 \\
\hline Pit1- 6 & $08043^{\prime} 28.5^{\prime \prime}$ & 0040 29'04.0" & 332 & Pit $2-6$ & $\begin{array}{l}080 \\
43.403\end{array}$ & 0040 29.562' & 316 \\
\hline Pit $1-7$ & $08043^{\prime} 29.3^{\prime \prime}$ & 0040 29'04.3" & 331 & Pit $2-7$ & $\begin{array}{l}080 \\
43.410^{\prime}\end{array}$ & $004029.577^{\prime}$ & 309 \\
\hline Pit 1-8 & $08043^{\prime} 28.1^{\prime \prime}$ & 0040 29'04.5" & 328 & Pit $2-8$ & $\begin{array}{l}080 \\
43.400\end{array}$ & $004029.575^{\prime}$ & 316 \\
\hline Pit $1-9$ & $08043^{\prime} 29.0^{\prime \prime}$ & $004029^{\prime} 04.0 "$ & 329 & Pit $2-9$ & $\begin{array}{l}080 \\
43.404^{\prime}\end{array}$ & 0040 29.583' & 314 \\
\hline Pit 1-10 & $08043^{\prime} 29.5^{\prime \prime}$ & 0040 29'04.4" & 327 & Pit $2-10$ & $\begin{array}{l}080 \\
43.413^{\prime}\end{array}$ & $004029.5411^{\prime}$ & 317 \\
\hline
\end{tabular}




\section{MATERIALS AND METHODS}

Ten trial pits were dug at each location. Disturbed samples were taken at intervals where changes in soil characteristics were observed up to the depths where lateritized bsaement rock was encountered. The shallowest pit was $4.5 \mathrm{~m}$ while the deepest was $1.65 \mathrm{~m}$. Classification tests including sieve analysis, consistency limits, specific gravity and natural moisture content were carried out on samples taken from the trial pits. Shear box test, consolidation, compaction, California bearing ratio and permeability were also carried out on these samples while cone penetrometer test was carried out in the field.

Cone pentrometer test was performed using 20 tones capacity hand penetrometer. With this arrangement, it was possible to measure both the point and frictinal resistance in the trial pits to the point of stiff resistance encountered at the lateritized basement top encountered at varying depths of either $0.4 \mathrm{~m}, 1.0 \mathrm{~m}$ or $1.65 \mathrm{~m}$. The dial guages used were calibrated prior to commencement of the tests. All laboratory tests were carried out using the British standard procedure 1377 of 1990. Modifications were however made where necessary. The bearing capapcity parameters were obtained from shear box test while bearing capacities were calculated using Terzaghi's bearing capacity equation for shallow strip footing (Equation 1). The safe bearing capacities were calculated using a factor of safety of 3 and equation 2 . The depths used in the calculation of the bearing capacities were generaly higher than their width.

$$
\begin{aligned}
& Q_{u}=c N c+\gamma D N q+0.5 y B N y \\
& Q S=\frac{Q_{u}}{3}+\gamma D
\end{aligned}
$$

Where; $Q_{u}$; Ultimate bearing capacity, QS; safe bearing capacity; $c=$ cohesion of soil $\left(\mathrm{kN} / \mathrm{m}^{2}\right) ; \mathrm{\gamma}=$ effective unit weight of soil $\left(\mathrm{kN} / \mathrm{m}^{3}\right)$; $D=$ depth of footing $(m)$. Values of bearing capacity factors: $\mathrm{Nc}, \mathrm{Nq}$ and $\mathrm{Ny}$ for different angles of internal friction, $\phi$ were as proposed by Terzaghi.

\section{RESULTS AND DISCUSSIONS Classification Tests}

This category of tests were carried out on samples taken from 20 trial pits at varrying depths from the two locations. The results showed that these samples consist mostly of poorly graded gravely sands with little fines. The amount of medium to coarse grained sand fraction were averagely above $85 \%$ in the studied soils. At deper depths however, the samples contained more gravel. Figure 2 shows some grading curves of the studied soils while Figure 3 presents the bar charts of their grain size distribution. Specific gravity ranged from 2.40 to 2.75 for location one, it ranged from 2.64 to 2.67 for the second location. For location one, natural moisture content ranged from $1.5 \%$ and $6.8 \%$, while it ranged from $1.5 \%$ to $6.8 \%$ at location two. Only few samples with appreciable amount of fines and plasticity were tested for consistency limits because of the general granular nature of the soils in the study area. For location one, liquid limit ranged from $29 \%$ to $34 \%$, plastic limit ranged from $18 \%$ to $25 \%$ while plasticity index averages $10.5 \%$. The liquid limit for location two ranged from $32 \%$ to $34 \%$, plastic limit ranged from $22 \%$ to $23.5 \%$ while plasticity index averages $10 \%$. Casagrande plasticity chart classify soils from the two locations as inorganic to medium plasticity soil.

Most soil samples from both locations classify as A-2 -4 under the AASHTO classification system, rating as good subgrade materials. Bulk density, dry density, specific gravity and natural moisture content increases with depth. These parameters vary significantly a 0.05 with depth with natural moisture content and dry density having the strongest correlation with increse in sampling depths as shown in Figure 4 


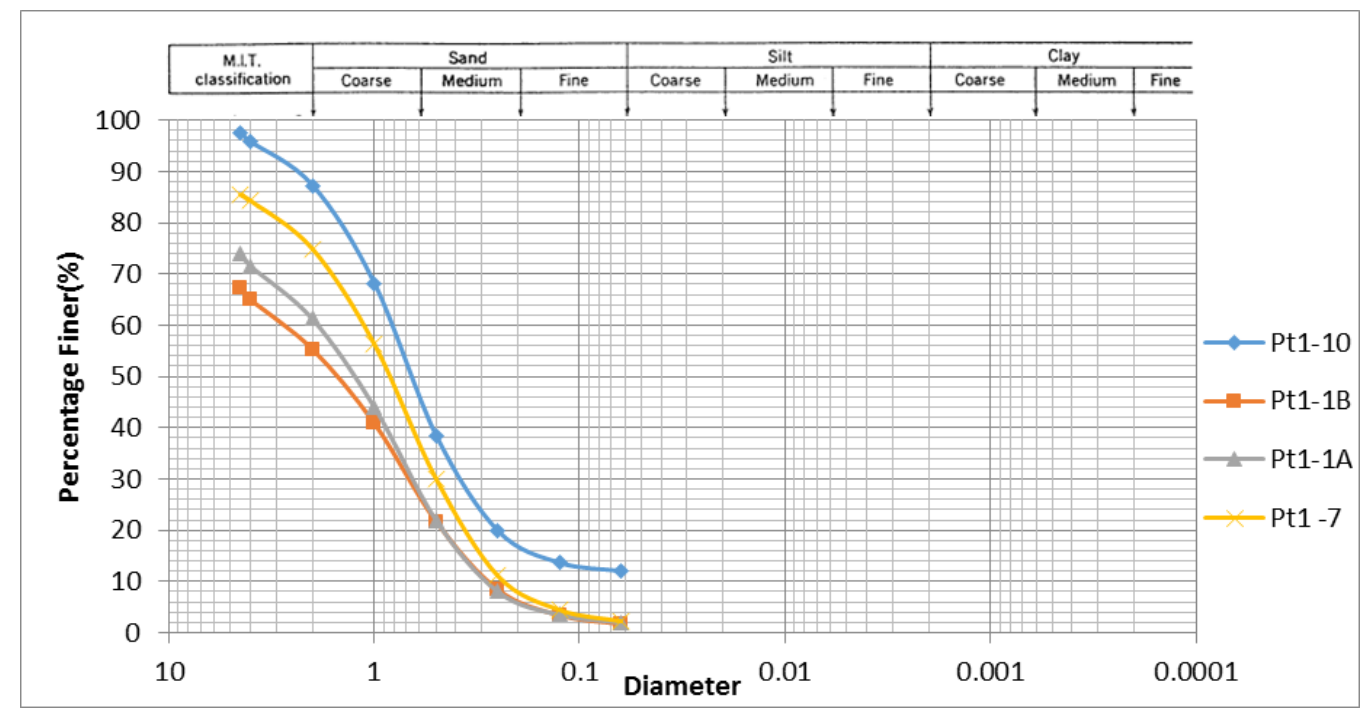

Figure 2: Grading curves of some soil samples from the study area.
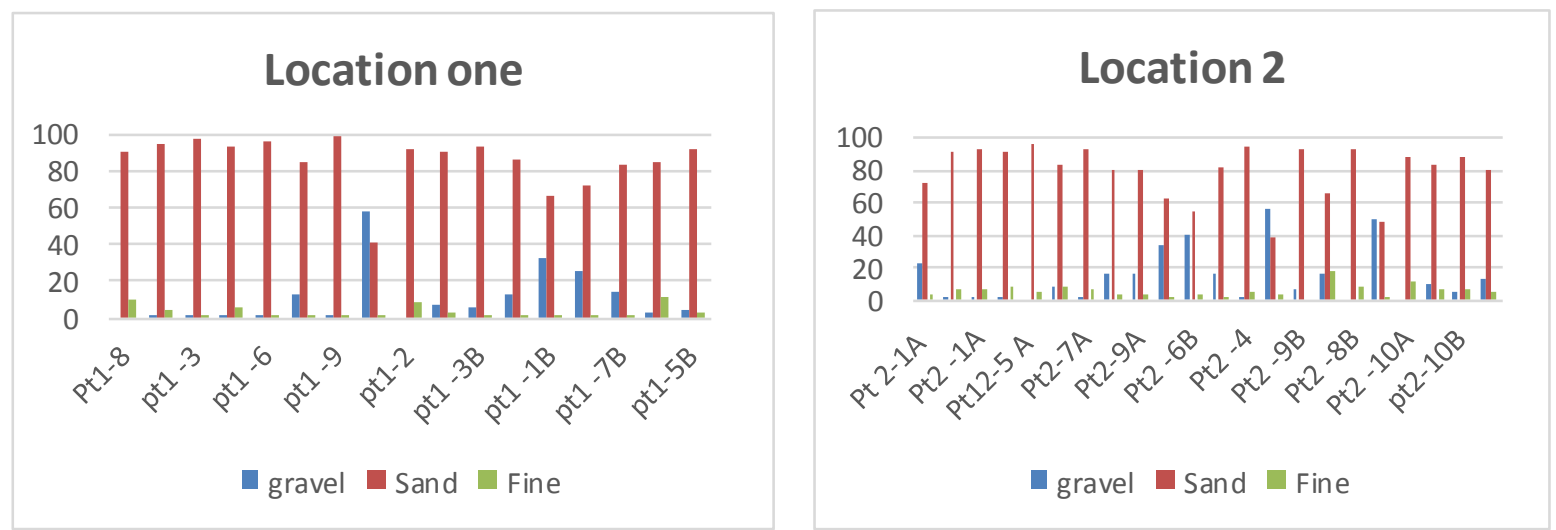

Figure 3: Bar showing the grain size distributions of sanples from both locations.

The density of a coarse grained soil is a deirect indication of its stiffness and strength. The bulk density characteristic of the sampled soils ranged from $1.44 \mathrm{~g} / \mathrm{cm}^{3}$ to $1.81 \mathrm{~g} / \mathrm{cm}^{3}$ in location one and from $1.55 \mathrm{~g} / \mathrm{m}^{3}$ to $1.88 \mathrm{~g} / \mathrm{m}^{3}$ in location two.

The dry density of soil samples from location one ranged from $1.36 \mathrm{~g} / \mathrm{m}^{3}$ to $1.76 \mathrm{~g} / \mathrm{m}^{3}$ while it ranged between $1.51 \mathrm{~g} / \mathrm{m}^{3}$ to $1.80 \mathrm{~g} / \mathrm{cm}^{3}$ for location two soil samples. These values are typical of dense sands.

Figure 5 shows a strong positive correlation between bulk density and dry density of the studied soils.

\section{Cone Penetrometer Test}

The CPT values for location one ranged from $750 \mathrm{kN} / \mathrm{m}^{2}$ to $950 \mathrm{kN} / \mathrm{m}^{2}$ while that of location two ranged from $700 \mathrm{kN} / \mathrm{m}^{2}$ to $850 \mathrm{kN} / \mathrm{m}^{2}$. The highest CPT values were gotten at the depths where laterised hardpans were encountered at various depths as shown in table 2. The top of the lateritized basement is generally favourable for foundation of structures because of its characteristic high CPT values in all the trial pits.

\section{Shear Strength and Safe Bearing Capacity}

The highest bearing capacity values were recorded between $1 \mathrm{~m}$ and $1.2 \mathrm{~m}$ which is made up of gravelly silty sand at the top of the laterised basement rock in different pits. 
Bearing capacity increases with sampling depth with correlation coefficient up to 0.99 . Table 3 and 4 show the bearing capacity values for both locations. Fig. 6 shows how bearing capacity varies with depth in some trial pits. Using a factor of safety of 3 , the safe bearing capacities calculated for strip footing ranged from 395
$\mathrm{kN} / \mathrm{m}^{2}$ to $2,421 \mathrm{kN} / \mathrm{m}^{2}$. Although, these values are high enough for the development of normal functional buildings, it is advisable to place foundations on the lateritized basement for heavier buildings since depth to this weathered bed rock is shallow.

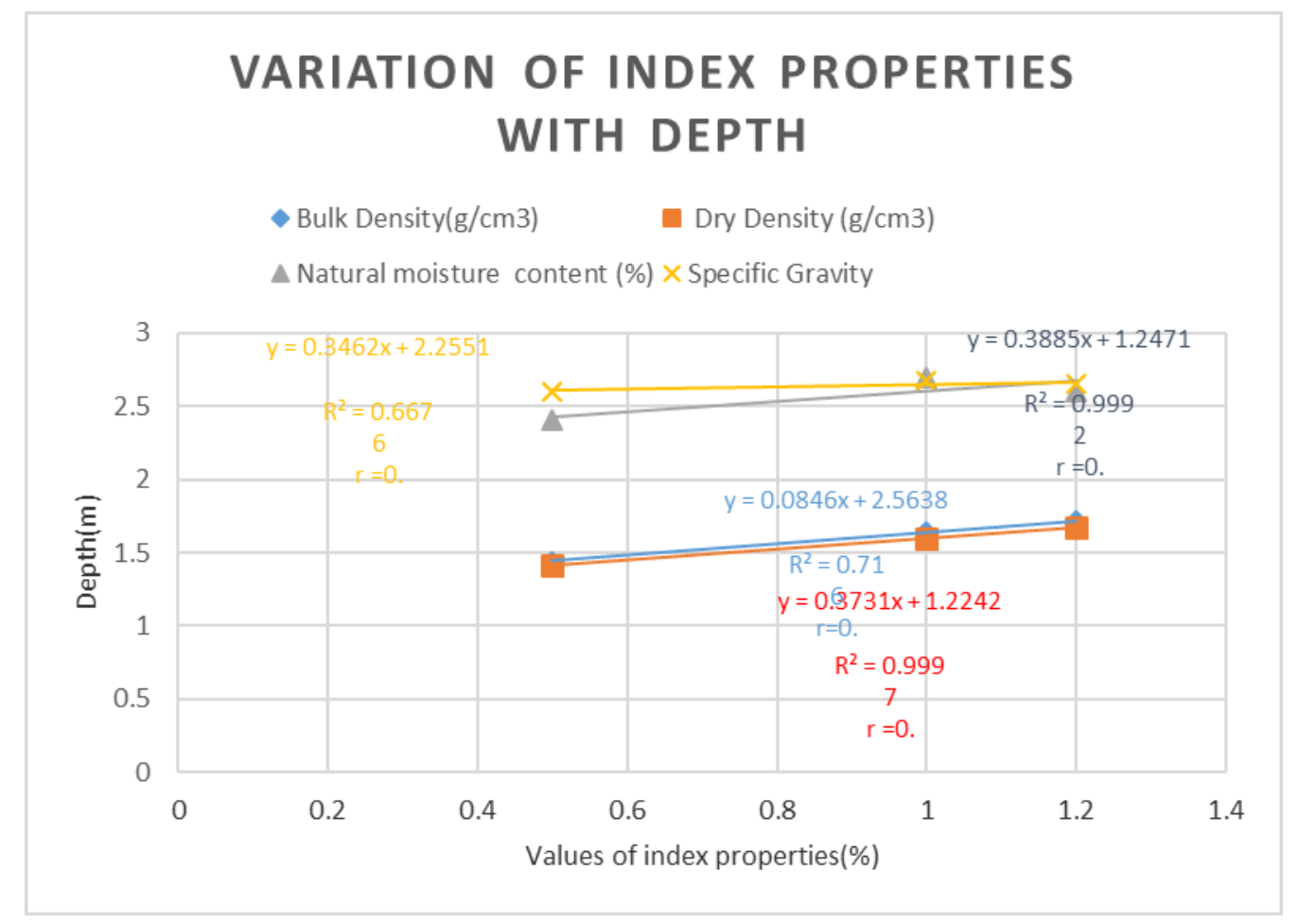

Figure 4: Variation of some index properties with depth.

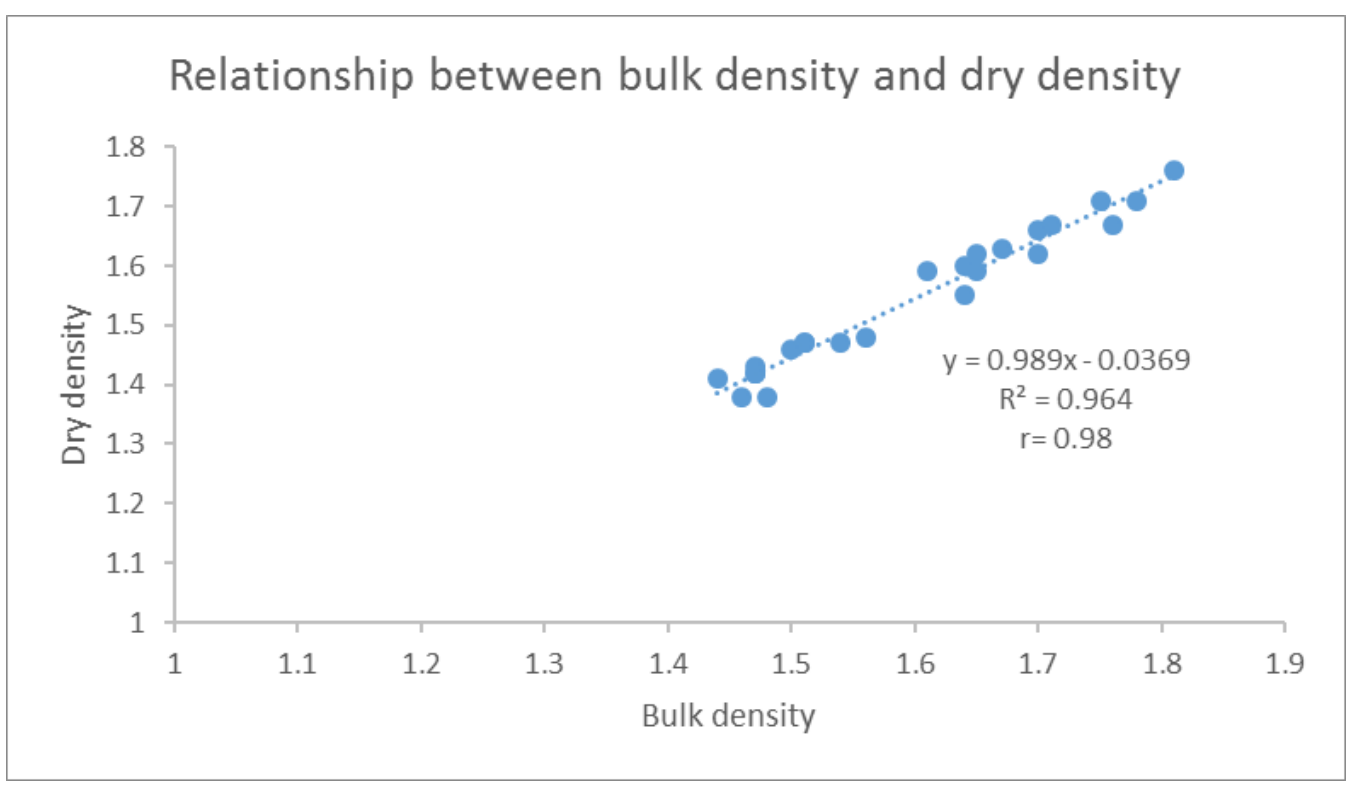

Figure 5: Relationship between bulk density and dry density. 
Owoyemi and Awojobi: Assessment of Index Properties and Bearing Capacities of Soils for........

Table 2: Result of Cone Penetrometer Test

\begin{tabular}{llllll}
\hline & Location 1 & & \multicolumn{3}{c}{ Location 2 } \\
\hline Test & Depth(m) & $\begin{array}{l}\text { CPT Value } \\
\left(\mathbf{k N} / \mathbf{m}^{2}\right)\end{array}$ & Test location & Depth(m) & $\begin{array}{l}\text { CPT Value } \\
\left(\mathbf{k N} / \mathbf{m}^{2}\right)\end{array}$ \\
PT1-2C & 1.65 & 800 & Pt2-1A & 0.8 & 850 \\
PT1-3C & 1.2 & 850 & Pt2-2A & 0.4 & 800 \\
PT1-4B & 0.9 & 850 & Pt2 -3A & 0.4 & 750 \\
PT1-5B & 0.7 & 850 & Pt2-4A & 0.2 & 800 \\
PT1-6B & 0.8 & 850 & Pt2-5A & 0.2 & 850 \\
PT1-7B & 1.0 & 900 & Pt2-6A & 0.3 & 750 \\
PT1-8C & 1.3 & 750 & Pt2-7A & 0.5 & 900 \\
PT1-9B & 0.45 & 850 & Pt2-8A & 0.5 & 800 \\
PT1-10B & 0.55 & 950 & Pt2-8B & 1.0 & 850 \\
& & & Pt2-9B & 1.0 & 700 \\
& & & Pt2-10A & 0.5 & 750 \\
& & & Pt2-10B & 1.0 & 850 \\
\hline
\end{tabular}

Table 3: Shear Strength and Safe bearing capacity values for locaion 1

\begin{tabular}{|c|c|c|c|c|c|}
\hline $\begin{array}{l}\text { Test } \\
\text { location }\end{array}$ & Depth(m) & $\begin{array}{l}\text { Angle of internal } \\
\text { Friction }\left({ }^{\circ}\right)\end{array}$ & $\begin{array}{l}\text { Cohesion } \\
\left(\mathrm{kN} / \mathrm{m}^{2}\right)\end{array}$ & $\begin{array}{l}\text { Shear } \\
\text { Strength } \\
\left(\mathrm{kN} / \mathrm{m}^{2}\right)\end{array}$ & $\begin{array}{l}\text { Safe Bearing } \\
\text { Capacity } \\
\left(\mathrm{kN} / \mathrm{m}^{2}\right)\end{array}$ \\
\hline PT2 -1A & 0.5 & 40 & 0 & 272 & 419 \\
\hline PT2-1B & 0.8 & 37 & 2 & 246 & 473 \\
\hline PT2-2A & 0.4 & 38 & 4 & 257 & 448 \\
\hline PT2-3A & 0.4 & 41 & 0 & 282 & 230 \\
\hline РT24A & 0.3 & 41 & 5 & 287 & 404 \\
\hline PT2-5A & 0.2 & 39 & 8 & 271 & 413 \\
\hline PT2-6A & 0.3 & 38 & 0 & 257 & 188 \\
\hline PT2-7A & 0.5 & 37 & 5 & 249 & 414 \\
\hline PT2-8A & 0.5 & 38 & 0 & 257 & 435 \\
\hline PT2-8B & 1.0 & 37 & 0 & 244 & 473 \\
\hline РT2-9A & 0.5 & 37 & 5 & 249 & 429 \\
\hline PT2-9B & 1.0 & 37 & 5 & 249 & 550 \\
\hline PT2-10A & 9.5 & 40 & 5 & 277 & 551 \\
\hline РT2-10B & 1.0 & 37 & 10 & 254 & 716 \\
\hline
\end{tabular}

Compaction and Californian Bearing Ratio Samples from the two locations have good compaction parameters when compacted using the modified AASHTO (American Association of State Highway Transportation Officials) method. For location one, the maximum dry density ranged from $2000 \mathrm{~kg} / \mathrm{m}^{3}$ to $2006 \mathrm{~kg} / \mathrm{m}^{3}$, while optimum moisture content ranged from $9.6 \%$ to $11.6 \%$. For location two, the maximum dry density ranged from $2000 \mathrm{~kg} / \mathrm{m}^{3}$ to $2040 \mathrm{~kg} / \mathrm{m}^{3}$, while optimum moisture content ranged from $7.5 \%$ to $8.5 \%$. This indicates that the studied soils require only little moisture increase to achieve good compaction. 
Nigerian Journal of Basic and Applied Science (June, 2016), 24(1): 82-89

Table 4: Shear Strength and Safe bearing capacity values for locaion 2

\begin{tabular}{llllll}
\hline $\begin{array}{l}\text { Test } \\
\text { location }\end{array}$ & Depth $(\mathrm{m})$ & $\begin{array}{l}\text { Angle of internal } \\
\text { Friction }(0)\end{array}$ & $\begin{array}{l}\text { Cohesion } \\
\left(\mathrm{kN} / \mathrm{m}^{2}\right)\end{array}$ & $\begin{array}{l}\text { Shear } \\
\text { Strength } \\
\left(\mathrm{kN} / \mathrm{m}^{2}\right)\end{array}$ & $\begin{array}{l}\text { Safe Bearing } \\
\text { Capacity } \\
\left(\mathrm{kN} / \mathrm{m}^{2}\right)\end{array}$ \\
\hline PT1-1A & 0.5 & 37 & 0 & 224 & 355 \\
PT1-1B & 1.0 & 42 & 0 & 292 & 992 \\
PT1-1C & 1.2 & 45 & 8 & 332 & 2,421 \\
PT1-2A & 0.6 & 30 & 0 & 187 & 108 \\
PT1-2B & 1.3 & 33 & 0 & 211 & 305 \\
PT1-2C & 1.65 & 33 & 0 & 211 & 413 \\
PT1-3A & 0.6 & 33 & 0 & 211 & 176 \\
PT1-3B & 1.0 & 33 & 0 & 211 & 257 \\
PT1-3C & 1.2 & 38 & 0 & 253 & 643 \\
PT1-4A & 0.5 & 34 & 0 & 219 & 165 \\
PT1-4B & 0.9 & 36 & 0 & 236 & 351 \\
PT1-5A & 0.5 & 38 & 0 & 253 & 312 \\
PT1-5B & 0.7 & 46 & 0 & 336 & 1,268 \\
PT1-6A & 0.5 & 36 & 0 & 236 & 302 \\
PT1-6B & 0.8 & 37 & 0 & 244 & 408 \\
PT1-7A & 0.5 & 32 & 4 & 236 & 226 \\
PT1-7B & 1.0 & 33 & 0 & 244 & 276 \\
PT1-8A & 0.5 & 37 & 5 & 239 & 382 \\
PT1-8B & 1.0 & 37 & 5 & 239 & 523 \\
PT1-8C & 1.3 & 37 & 5 & 239 & 688 \\
PT1-9A & 0.3 & 37 & 5 & 239 & 387 \\
PT1-9B & 0.45 & 38 & 5 & 258 & 483 \\
PT1-10A & 0.5 & 37 & 0 & 253 & 407 \\
PT1-10B & 0.55 & 38 & 055 & 395 \\
\hline
\end{tabular}

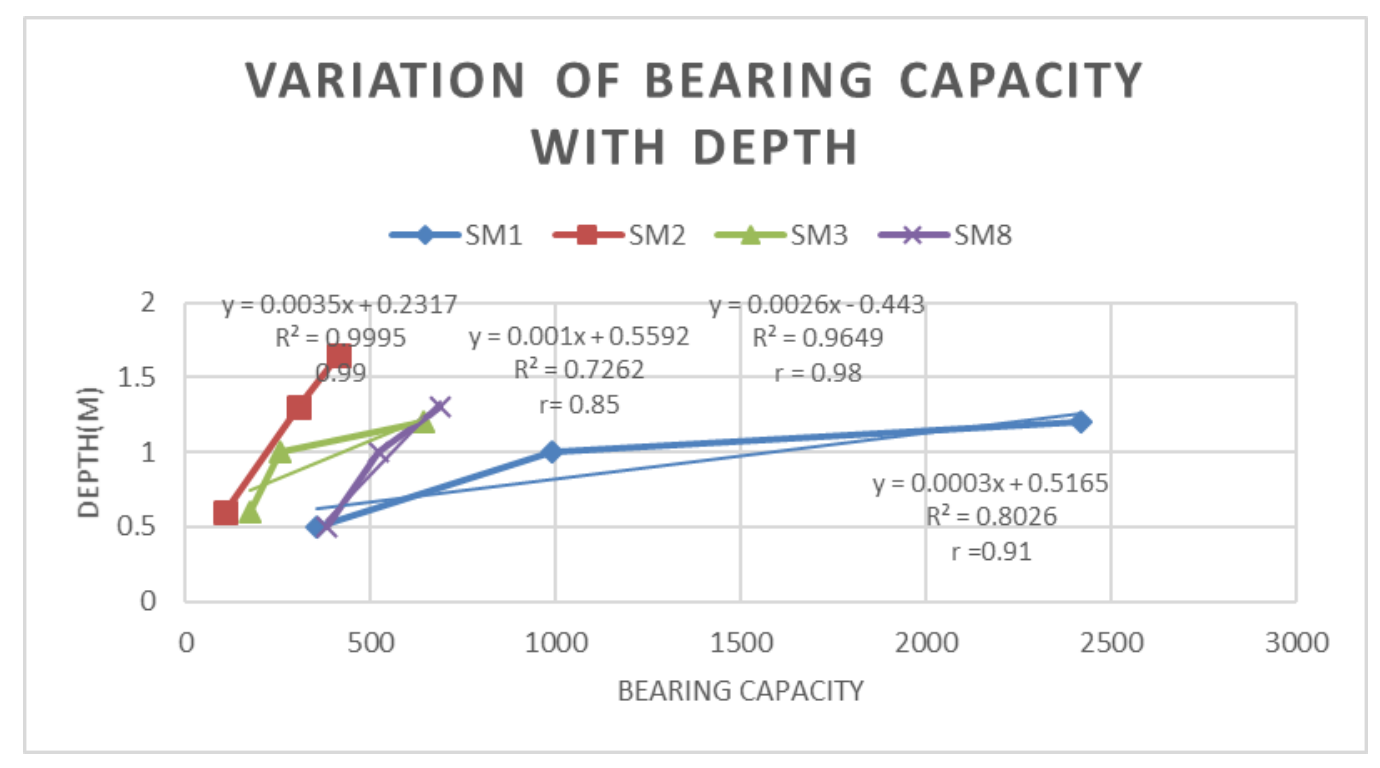

Figure 6: Variation of Bearing capacity with Depth 


\section{Consolidation and Permeabilty}

The consolidation test shows that, coefficient of compressibility and coefficient of volume change are as low as $2 \times 10^{-3} \mathrm{~m}^{2} / \mathrm{kN}$ and $1.2 \times 10^{-3} \mathrm{~m}^{2} / \mathrm{kN}$ respectively for location one while estimated amount of settlement is $12 \mathrm{~mm}$. The coefficient of compressibility and coefficient of volume change are as low as $2.5 \times 10^{-3} \mathrm{~m}^{2} / \mathrm{kN}$ and $1.7 \times 10^{-3} \mathrm{~m}^{2} / \mathrm{kN}$ respectively for location two while the estimated amount of settlement above the lateritized basement is $19 \mathrm{~mm}$. Skempton and McDonald (1956) proposed a limiting amount of settlement up to $35 \mathrm{~mm}$ for shallow foundations on sandy soil. Although, the estimated amount of settlment for both locations are within acceptable limits, in order to avoid differential settlement due to spatial variation in top soil compressibility, it is safer to put infrastructure foundations on the lateritized basement rock. The top soil on the lateritized basement generally has high to medium permeability.

\section{REFERENCES}

Aduoye, G.O and Agbede, O.A. (2014) Bearing Capacity Determination by Multiple Regression. Journal of Multidisciplinary Engineering Science and Technology, 1(5): $285-286$.

Avwenagha, E., Akpokodje, E. G. and Tse, A. C (2014) Geotechnical Properties of Subsurface Soils in Warri, Western Niger Delta, Nigeria. Journal of Earth Sciences and Geotechnical Engineering, 4(1): 89 - 102.

British, Standard Institute (1990) Methods for Tests for soils for civil Engineering Purposes. B.S 1377.

Ige, $\quad 0.0$ and Ogunsanwo, $0 . \quad$ (2009) Environmental geological assessment of a Solid Waste Disposal site: a case in Ilorin, Southwestern, Nigeria. Nature and Science, 1(6): 53-62.

Nwankwoala, H.O and Warmate, T. (2014) Subsurface Soil Characterization of a Site for Infrastructural Development Purposes in D/Line, Port Harcourt, Nigeria. American International Journal of Contemporary Research, 4(6): 139148.

\section{CONCLUSION}

The importance of detailed geotechnical investigation for building foundations cannot be over emphasized. The soil located in the study area exhibit adequate bearing capacities. Soil samples from both locations in the study area classify as poorly graded gravely sands with little fines. These soils belong to group A-2-4 of the AASHTO classification system. The soil from the two locations exhibit good compaction parameters when compacted with high energy. They have low compressibility and medium to high permeability. Apart from specific gravity, other classification parameters vary significantly with depth. Safe bearing capacity also increases with depth, therefore a deeper depth especially the lateritized basement top is the most favourable for infrastructure foundations in the area.

Ogunsanwo, .O. (2002) Effect of inundation on the geotechnical properties of some soils from parts of southwestern Nigeria. Journal of Mining and Geology, 38(1): $57-63$.

Ola, S.A. (1988) Geotechnical properties of Nigerian soils and ten years collaborative

research with Nigerian building and road research institute, (NBRRI). 189-218.

Oyedele, K.F., Oladele S. and Adedoyin O., (2011) Application of Geophysical and Geotechnical Methods to Site Characterization for Construction Purposes at Ikoyi, Lagos, Nigeria. Journal of Earth Sciences and Geotechnical Engineering, 1(1): 139 148.

Skempton, A. W. and MacDonald, D. H., (1956) Allowable settlement of buildings. Proc. Inst. Civ. Engrs.5, Pt. III, 727-768. 